\title{
Recent summer sea ice thickness surveys in Fram Strait and associated ice volume fluxes
}

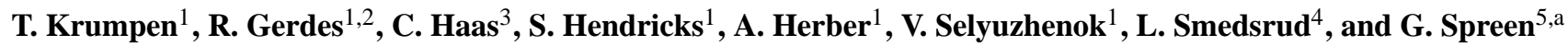 \\ ${ }^{1}$ Alfred Wegener Institute, Busse Str. 24, 27570 Bremerhaven, Germany \\ ${ }^{2}$ Jacobs University, Earth and Environmental Sciences Faculty, Campus Ring 1, 28759 Bremen, Germany \\ ${ }^{3}$ York University, Earth \& Space Science \& Engineering, Petrie 105, 4700 Keele St, Toronto, ON M3J 1P3, Canada \\ ${ }^{4}$ Geophysical Institute, University Bergen, Allegt. 70, 5020 Bergen, Norway \\ ${ }^{5}$ Norwegian Polar Institute, Fram Centre, Postbox 6606 Langnes, 9296 Troms $\varnothing$, Norway \\ a now at: University of Bremen, Institute of Environmental Physics, Otto-Hahn-Allee 1, 28359 Bremen, Germany
}

Correspondence to: T. Krumpen (thomas.krumpen@awi.de)

Received: 6 August 2015 - Published in The Cryosphere Discuss.: 30 September 2015

Revised: 13 January 2016 - Accepted: 21 January 2016 - Published: 8 March 2016

\begin{abstract}
Fram Strait is the main gateway for sea ice export out of the Arctic Ocean, and therefore observations there give insight into the composition and properties of Arctic sea ice in general and how it varies over time. A data set of ground-based and airborne electromagnetic ice thickness measurements collected during summer between 2001 and 2012 is presented here, including long transects well into the southern part of the Transpolar Drift obtained using fixedwing aircrafts. The primary source of the surveyed sea ice leaving Fram Strait is the Laptev Sea and its age has decreased from 3 to 2 years between 1990 and 2012. The thickness data consistently also show a general thinning of sea ice for the last decade, with a decrease in modal thickness of second year and multiyear ice, and a decrease in mean thickness and fraction of ice thicker than $3 \mathrm{~m}$. Local melting in the strait was investigated in two surveys performed in the downstream direction, showing a decrease in sea ice thickness of $0.19 \mathrm{~m} \mathrm{degree}^{-1}$ latitude south of $81^{\circ} \mathrm{N}$. Further north variability in ice thickness is more related to differences in age and deformation. The thickness observations were combined with ice area export estimates to calculate summer volume fluxes of sea ice. While satellite data show that monthly ice area export had positive trends since 1980 $\left(10.9 \times 10^{3} \mathrm{~km}^{2}\right.$ decade $\left.^{-1}\right)$, the summer (July and August) ice area export is low with high uncertainties. The average volume export amounts to $16.78 \mathrm{~km}^{3}$. Naturally, the volume flux estimates are limited to the period when airborne thickness surveys are available. Nevertheless, we could show that
\end{abstract}

the combination of satellite data and airborne observations can be used to determine volume fluxes through Fram Strait and as such, can be used to bridge the lack of satellite-based sea ice thickness information in summer.

\section{Introduction}

Arctic sea ice extent and thickness have undergone dramatic changes in the past decades: summer sea ice extent has declined at a rate of approximately $12.7 \%$ decade $^{-1}$ over the satellite record (Meier et al., 2014; Comiso and Hall, 2014, 1978-present) and its mean thickness has decreased by $0.58 \pm 0.07$ m decade $^{-1}$ over the period 2000-2012 (Lindsay and Schweiger, 2015). The thinning of sea ice is accompanied by an increase of ice drift velocity (Spreen et al., 2011), deformation (Rampal et al., 2009; Martin et al., 2014) and a decrease of net ice growth rates (Holland et al., 2010). Climate model simulations indicate that ice extent and thickness will further decline through the 21 st century in response to atmospheric greenhouse gas increases (Stroeve and Notz, 2015). The mass balance of Arctic sea ice is therefore determined not only by changes in the energy balance of the coupled ice-ocean-atmosphere system but also by the increasing influence of dynamic effects. One aspect of the mass balance of Arctic sea ice are changes of ice volume export rates through Fram Strait, the major sea ice outflow gate of the Arctic. These strongly impact ocean processes further south. 
Trends in southern Fram Strait sea ice thickness were previously investigated by Hansen et al. (2013) and Renner et al. (2014). Based on a 21 year long time series (1990-2011) obtained from moored sonar, Hansen et al. (2013) showed that the ice thickness at $79^{\circ} \mathrm{N}$ decreased from an annual mean of $3.0 \mathrm{~m}$ during the $1990 \mathrm{~s}$ to $2.2 \mathrm{~m}$ during 2008-2011. Renner et al. (2014) reported an even more pronounced thinning of Fram Strait ice cover. According to in situ and airborne observations carried out at the end of the melt season, ice thickness decreased by over $50 \%$ during 2003-2012. The first aim of this paper is to complement those recent findings by means of a data set of electromagnetic (EM) ice thickness observations carried out during summer in northern Fram Strait and the southern part of the Nansen Basin. Measurements were obtained in the months of July and August of 2001, 2004 and 2010-2012 during two cruises of the German ice-breaker RV Polarstern and three airborne campaigns with the German DC3-T research aircraft Polar 5. An investigation of backtrajectories of surveyed sea ice using satellite-based sea ice motion data will allow us to examine the connection between thickness variability, ice age and source area.

A second objective of this paper is to investigate acrossand along-Fram Strait gradients in sea ice thickness. According to ULS observations of Hansen et al. (2013), the ice thickness distribution in Fram Strait is characterized by a gradient from thicker ice in the west to thinner ice in the east. The high interannual and seasonal variability of this gradient is related to the thickness and age of ice that enters Fram Strait. Both vary substantially since ice originates from different regions and had a different dynamic and thermodynamic history on its way through the Arctic Ocean (Rabenstein et al., 2010). The long operating distance of Polar 5 enabled us to obtain the first continuous ice thickness measurements across, but also along Fram Strait. Below, we compare across-strait gradients obtained from Polar 5 surveys to gradients observed further south by Renner et al. (2014) and Hansen et al. (2013). Surveys performed in the downstream direction are used to investigate local melt, associated with atmospheric and oceanic processes acting on southward drifting sea ice.

A third objective of this paper is to use the presented EM measurements together with satellite-based area flux estimates to calculate volume outflows for the periods when thickness surveys where made. Whether sea ice volume loss through Fram Strait accelerates is currently under discussion. Following Smedsrud et al. (2011), the decrease in Fram Strait ice thickness is accompanied by an increase in ice area export out of Fram Strait. Those authors used geostrophic winds derived from reanalysis data to calculate the ice area export between Spitsbergen and Greenland and found it to be about $25 \%$ larger than during the 1960s. In contrast, other studies (Kwok, 2009; Kwok et al., 2013) did not observe any significant trend in ice area export for the past decades. Only a few studies exist that quantify Fram Strait volume fluxes using satellite data directly. By combining sea ice concentra- tion and drift from passive microwave satellites and thickness derived from ICESat laser altimetry, Spreen et al. (2009) determined the sea ice volume flux in the Fram Strait region for 11, one month long ICESat observation periods in spring and late autumn. However, volume flux estimates with thickness information obtained from altimeter satellites missions such as ICESat or CryoSat-2 are restricted to the period between October and April. Hence, little is known about sea ice volume fluxes through Fram Strait in the summer months. An approximation of sea ice volume flux during summer by means of AEM thickness observations and satellite drift and concentration data is the first of its kind. These estimates shall improve the understanding of interannual variability in summer sea ice outflow and complement existing winter volume flux calculations.

\section{Data}

\subsection{EM ice thickness measurements}

EM ice thickness measurements utilize the contrast of electrical conductivity between sea water and sea ice to determine the distance of the instrument to the ice-water interface (Haas et al., 2009). In 2001 during the RV Polarstern cruise (ARK-XVII/2), only ground-based EM (GEM) data were obtained using an instrument (Geonics EM31Mk2) pulled on a sledge across the ice (Haas, 2004). With GEM measurements, the distance to the ice-water interface corresponds to the ice plus snow thickness (hereafter referred to as EM ice thickness). After 2001, measurements were made with an airborne EM (AEM) system towed 12 to $20 \mathrm{~m}$ above the ice surface. Here, the distance to the uppermost snow surface is determined with a laser altimeter. The ice plus snow thickness is then calculated as the difference between the laser and EM derived distance (Haas et al., 2009). In 2004, AEM measurements were conducted with a helicopter operated from RV Polarstern (cruise ARK-XX/2) along triangular flight tracks with a side length of 40 to $80 \mathrm{~km}$ (Haas et al., 2008). In 2010, 2011 and 2012 AEM surveys were conducted with the Polar 5 aircraft during the TIFAX (Thick Ice Feeding Arctic Export) campaigns operating from the Danish Station Nord in Nord-East Greenland (Haas et al., 2010). These airplane surveys allow the acquisition of hundreds of kilometers of data along straight flight lines. An overview of the flight tracks surveyed during the individual field campaigns is given in Fig. 1.

The accuracy of the EM measurements is of the order of $\pm 0.1 \mathrm{~m}$ over level sea ice (Pfaffling et al., 2007). However, the maximum thickness of pressure ridges can be underestimated by as much as $50 \%$. The underestimation of peak pressure ridge thickness is a result of footprint smoothing, an effect that is mass-conserving for mean thickness values on the kilometer scale (Lindsay and Schweiger, 2015; Mahoney et al., 2014). The thickness PDFs for all profiles presented in 

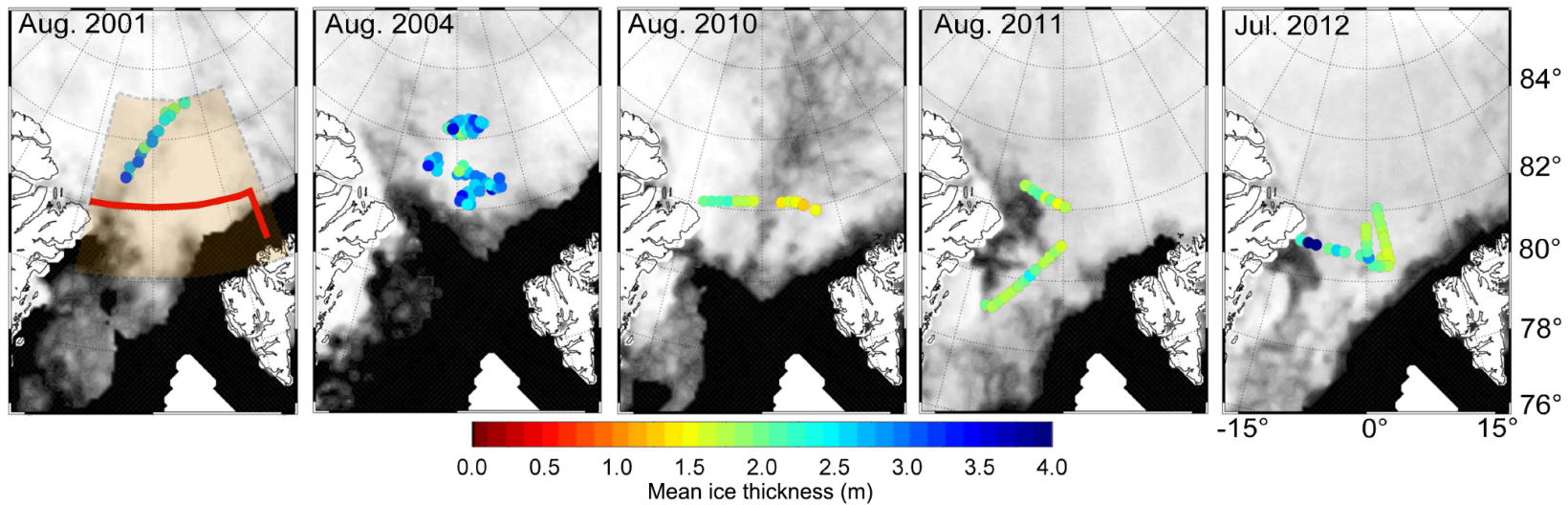

Figure 1. Overview of all EM ice thickness measurements obtained in the Fram Strait region during two cruises with the German ice-breaker RV Polarstern (August 2001 and 2004) and three surveys with the research aircraft Polar 5 (August 2010 and 2011, July 2012). The color coding of the EM profiles corresponds to the mean ice thickness of $10 \mathrm{~km}$ sections. The light red shaded area marks the area of interest with the data acquisitions used in this analysis. Ice concentration from the date of the first flight of each campaign, is plotted in the background going from $0 \%$ ice concentration in black to $100 \%$ in white. The thick red line in the left panel indicates the meridional and zonal gates through which satellite-derived ice area fluxes were calculated.

this paper were calculated from histograms with a bin width of $0.1 \mathrm{~m}$. The most frequently occurring ice thickness, the mode of the distribution, represents level ice thickness and is the result of winter accretion and summer ablation. Because ridge thicknesses are in general underestimated in AEM data, the mode is most representative of the ice thickness PDF. The fraction of dynamically deformed ice is represented by the length and the shape of the tail of the thickness distribution. In this study, the fraction of ice thicker than $3 \mathrm{~m}$ is used to give a relative estimate of the amount of deformed ice. The mean thickness is used to quantify the overall decline in sea ice thickness. Note that before calculating mean and modal thickness from the PDFs, thin ice (less than $0.15 \mathrm{~m}$ ) and open water were excluded from the analysis. For the investigation of across and along Fram Strait thickness gradients, PDFs, mean and mode were calculated over a $25 \mathrm{~km}$ distance for meridional profiles (along Fram Strait) and zonal profiles (across Fram Strait). The distance is equivalent to the spacing between ULS observations of Hansen et al. (2013) at $79^{\circ} \mathrm{N}$.

Since per definition EM ice thickness measurements include the snow layer, interannual changes in ice thickness may not be solely related to changes in ice thickness, but also to changes in snow cover. During the presented EM surveys no snow measurements were made, except during the RV Polarstern cruises in 2001 and 2004, where a mean snow or weathered ice thickness of $0.07-0.1 \mathrm{~m}$ was observed. Therefore, and due to the general snow climatology of Arctic sea ice where snow completely melts in June and July leaving the ice surface bare in August and September (Maykut and Untersteiner, 1971; Warren et al., 1999), we assume a $0.1 \mathrm{~m}$ thick layer of weathered ice or snow to contribute to the total ice thickness. This assumption is also supported by snow or weathered layer observations in Fram Strait during the months of August and September by Renner et al. (2014). Variations may be due to episodic, short-lasting events of new snow accumulation which typically melt within a few days during July and August. Below we assume the unknown interannual variability of snow thickness to be equivalent to the averaged snow thickness uncertainty on multi-year ice for July and August $( \pm 5.0 \mathrm{~cm}$ ) provided by Warren et al. (1999).

The examination of interannual changes in the sea ice cover over a certain area requires continuous and overlapping measurements. Despite shortcomings due to logistical and meteorological challenges of air- and shipborne campaigns in the Arctic, we consider our data set to be sufficiently homogeneous with respect to its temporal and spatial coverage. Nevertheless, to ensure a maximum degree of consistency and to limit bias due to warm Atlantic Water (BeszczynskaMoeller et al., 2012), only flights obtained between 82 and $85^{\circ} \mathrm{N}$ and $13^{\circ} \mathrm{W}$ and $20^{\circ} \mathrm{E}$ were selected (compare the red shaded area in Fig. 1). A summary of the survey flights obtained during individual campaigns is presented in Table 1 together with survey dates and length of EM-profiles. In addition, the modal and mean ice thickness, as well as fraction of ice $\geq 3 \mathrm{~m}$ and the open-water fraction are given.

\subsection{Satellite data}

The interpretation of EM thickness measurements in a larger spatial context requires information about the age, drift history and source areas of the surveyed ice. Below we describe the data set that was used to determine age and drift trajectories. In addition, we present the approach to quantify ice area fluxes through Fram Strait. 
Table 1. The table summarizes for the area of interest and individual campaigns the dates of observations, platform, total profile length, the ice thickness (mode and mean $\pm \mathrm{SE}$ ), as well as the fraction of ice thicker than $3 \mathrm{~m}$ and the open-water fraction along profiles.

\begin{tabular}{|c|c|c|c|c|c|c|}
\hline Campaign & Platform & $\begin{array}{l}\text { Dates of } \\
\text { data takes }\end{array}$ & $\begin{array}{l}\text { Total profile } \\
\text { length }(\mathrm{km})\end{array}$ & $\begin{array}{l}\text { Ice thickness } \\
\text { Modal/Mean } \\
\pm \mathrm{SE}(\mathrm{m})\end{array}$ & $\begin{array}{l}\text { Fraction of } \\
\text { ice } \geq 3 \mathrm{~m}(\%)\end{array}$ & $\begin{array}{l}\text { Open-water } \\
\text { fraction (\%) }\end{array}$ \\
\hline $\begin{array}{l}\text { ARK-XVII/2, } 2001 \\
\text { (Haas, 2004) }\end{array}$ & RV Polarstern & 8-21 Aug 2001 & 50 & $2.0 / 2.58 \pm 1.1$ & 26 & - \\
\hline $\begin{array}{l}\text { ARK-XX/2, 2004 } \\
\text { (Haas et al., 2008) }\end{array}$ & RV Polarstern & $2-4,6-12,14$ Aug 2004 & 2270 & $2.2 / 2.59 \pm 1.3$ & 29 & 1.5 \\
\hline $\begin{array}{l}\text { TIFAX } 2010 \\
\text { (Haas et al., 2010) }\end{array}$ & Polar 5 & 19 and 22 Aug 2010 & 500 & $1.7 / 1.81 \pm 0.8$ & 8 & 4.7 \\
\hline TIFAX 2011 & Polar 5 & 2 and 4 Aug 2011 & 660 & $1.6 / 1.89 \pm 1.1$ & 10 & 10.5 \\
\hline TIFAX 2012 & Polar 5 & 19 and $21 \mathrm{Jul} 2012$ & 890 & $1.4 / 2.17 \pm 1.4$ & 15 & 3 \\
\hline
\end{tabular}

\subsubsection{Sea ice concentration}

Sea ice concentration data used in this study are obtained from the National Snow and Ice Data Center (NSIDC). The data set was derived using measurements from the Scanning Multichannel Microwave Radiometer (SMMR) aboard the Nimbus-7 satellite, from the Special Sensor Microwave/Imager (SSM/I) on the -F8, -F11 and -F13 satellites of the Defense Meteorological Satellite Program (DMSP), and from Microwave Imager/Sounder (SSMIS) aboard DMSP-F17. Sea ice concentration was calculated based on the Bootstrap algorithm (Comiso, 2000). Data are available on a daily basis at $25 \mathrm{~km} \times 25 \mathrm{~km}$ spatial resolution.

\subsubsection{Sea ice drift}

Passive-microwave retrieved ice drift products are provided by different institutions and have been widely used in sea ice studies and for model assimilation (e.g., Miller et al., 2006; Kwok, 2009; Spreen et al., 2011; Sumata et al., 2014). In this study, two different sets of ice drift products were used:

The first data set, Polar Pathfinder Sea Ice Motion Vectors (Version 2), was chosen because of its year-round availability. Below it is used to estimate transport rates out of Fram Strait, and to calculate ice drift trajectories during summer months from June to August. The Polar Pathfinder Sea Ice Motion product provided by the NSIDC contains daily gridded fields of sea ice motion on a $25 \mathrm{~km}$ Equal Area Scalable Earth grid (EASE) for the period between 1978 to 2012 (Fowler et al., 2013). The motion vectors (hereafter referred to as NSIDC) are obtained from a variety of satellite-based sensors such as the SMMR, SSM/I, AMSR-E and Advanced Very High Resolution Radiometer (AVHRR, only until 2004) and buoy observations from the International Arctic Buoy Program (IABP). In addition NCEP/NCAR winds are used as an ice drift estimator ( $1 \%$ of wind speed, $20^{\circ}$ turning angle) when no other data are available, which can happen more often during summer months. A description of the data set and the sea ice motion retrieval algorithm can be found in
Fowler et al. (2013). According to the authors, the uncertainty of the drift product is $1.0 \mathrm{~cm} \mathrm{~s}^{-1}$. However, with the progress of summer melting season, the error increases. By using SAR-based ice drift as a reference, Sumata et al. (2015) estimated the uncertainties to range from 1.0 to $2.0 \mathrm{~cm} \mathrm{~s}^{-1}$ between May and July, depending on drift speed and ice concentration.

In addition to NSIDC drift data, the tracking routine as described in Sect. 2.2.3 makes use of a second data set: sea ice motion provided by the Center for Satellite Exploitation and Research (CERSAT) at the Institut Francais de Recherche pour d'Exploitation de la Mer (IFREMER). Since a substantial part of Fram Strait sea ice originates from the Laptev Sea (Rigor and Colony, 1997), the calculation of drift trajectories requires a drift data set with good performance on the Siberian shelf. Following Rozman et al. (2011) and Krumpen et al. (2013), a comparison of different drift products with high-resolution satellite and in situ drift data in the Laptev Sea have shown that the CERSAT motion data has the highest accuracy in this region (less than $1.0 \mathrm{~cm} \mathrm{~s}^{-1}$ ). Hence, the ice drift data provided by CERSAT were used in the tracking approach, bridged with NSIDC data during summer months. The motion fields (hereafter referred to as CERSAT) are based on a combination of drift vectors estimated from scatterometer (SeaWinds/QuikSCAT and ASCAT/MetOp) and radiometer (SSM/I) data (Girard-Ardhuin and Ezraty , 2012). They are available with a grid size of $62.5 \mathrm{~km}$, using time intervals of 3 days for the period between September and May (1991 to present). Following Sumata et al. (2014), differences between low-resolution motion products are small for high ice concentration areas like the Transpolar Drift and the Laptev Sea during winter. We therefore believe the bias that may arise from blending two different motion data sets to be small, too.

\subsubsection{Sea ice pathways and source areas}

To determine drift trajectories and source areas of sampled sea ice we tracked the surveyed ice backward over a period of 
4 years using NSIDC and CERSAT ice drift and NSIDC ice concentration products. A specific ice area is tracked backwards until: (a) the ice reaches a position next to a coastline, (b) the ice concentration at a specific location reaches a threshold value of $\leq 15 \%$ when ice parcels are considered lost, or (c) the tracking time exceeds 4 years.

\subsubsection{Ice age}

Sea ice age information was obtained from the drift-age model of Maslanik et al. (2011). Ice age is retrieved by tracking sea ice from the formation until the melt or export using NSIDC ice concentration and drift data. The age information provided for each grid cell is the age of the oldest tracer parcel that exists in the grid cell. The data set is available on a $25 \mathrm{~km} \times 25 \mathrm{~km}$ grid with a temporal resolution of 1 week for the period between January 1990 and August 2013. For more details we refer to Maslanik et al. (2011).

\subsubsection{Ice area flux across Fram Strait}

In Sect. 3.4 we relate recent changes observed in Fram Strait ice thickness to satellite-based estimates of ice area flux. Ice area flux estimates out of Fram Strait are calculated using NSIDC motion estimates together with NSIDC ice concentration information. Flux estimates are made along a zonal gate positioned at $82^{\circ} \mathrm{N}$ between $12^{\circ} \mathrm{W}$ and $20^{\circ} \mathrm{E}$, and a meridional gate that connects the eastern end of the zonal gate with Spitsbergen $\left(80.6^{\circ} \mathrm{N}, 20^{\circ} \mathrm{E}\right.$, compare Fig. 1$)$. The ice area flux at the gates is the integral of the product between the meridional $(V)$ and zonal $(U)$ ice drift and ice concentration. In the following, ice area flux across Fram Strait is referred to as the sum of the meridional and zonal ice fluxes. A positive (negative) sign refers to an export out of (import into) the Arctic Ocean. Transport (flux) rates are given in $\mathrm{km}^{2} \mathrm{day}^{-1}$ or month ${ }^{-1}$. After removing the seasonal cycle, trends were calculated by linear regression, and significance at the $95 \%$ confidence level $(p)$ was determined with Student's $t$ test. The corresponding uncertainties of ice area fluxes are calculated as the integral of the product between NSIDC drift uncertainties provided by Fowler et al. (2013) and Sumata et al. (2015) and ice concentration. Following Fowler et al. (2013), we assume the uncertainty of ice drift velocity to be within the range of $1.0 \mathrm{~cm} \mathrm{~s}^{-1}$ during winter months (October-April). During summer months (MaySeptember), uncertainty estimates provided by Sumata et al. (2015) are applied ranging from $1.0-2.0 \mathrm{~cm} \mathrm{~s}^{-1}$, depending on ice drift velocity and ice concentration. Additional bias may arise from uncertainties in sea ice concentration data during summer months. Following Ivanova et al. (2014), the accuracy of sea ice concentration algorithms is lower during summer due to the presence of melt ponds, wind-roughened open-water areas and higher atmospheric humidity. The authors reported differences in sea ice concentration among 11 algorithms of up to $8 \%$ in September. Assuming the de- viation among algorithms to be a valid measure for the potential bias associated with the NDISC Bootstrap algorithm, results in an additional area flux uncertainty of $\pm 4 \%$ during summer months.

\section{Results and discussion}

\subsection{Fram Strait sea ice thickness, source area and age}

To investigate pathways and source areas of the surveyed ice, we used the location of the survey lines as starting points for the backtracking algorithm. Figure 2 shows the trajectories of ice surveyed in the area of interest between 2001 and 2012. The analysis shows that the largest fraction of the ice originated in the Laptev Sea. It took approximately $2-3$ years of drift with the Transpolar Drift until the ice was exported through Fram Strait. In contrast, the ice surveyed in 2010 west of the $0^{\circ}$ meridian mostly originated from the Beaufort Gyre.

Figure 3 compares the age of oldest ice (source: Maslanik et al., 2011) covered by EM measurements with the average age of oldest sea ice exiting through the meridional and zonal flux gates in summer (July-September). The time series shows a consistent decrease of the age of old Fram Strait sea ice at a rate of 0.6 years per decade. This result is significant at the $95 \%$ confidence level. The average age of the surveyed old ice between 2001 and 2012 is 2.56 years. The youngest ice was observed in 2012 (2.1 years), and the oldest ice was observed in 2004 ( 3.3 years). The surveyed ice had a slightly higher mean ice age than all ice of Fram Strait combined. However, the differences are within the standard deviation (SE) and therefore in reasonable agreement. The good agreement indicates that EM observations are representative for a larger Fram Strait area.

Figure 4 summarizes EM thickness data obtained between 2001 and 2012. Owing to the rather limited number of campaigns and the snapshot character of the surveys a trend analysis of the time series may be of limited value. Nevertheless, given the overlapping study regions and seasons and the large lengths of surveys, the EM data provide evidence of a changing Fram Strait sea ice cover that stands out of the interannual variability and bias that may arise from year to year varying snow cover $( \pm 5.0 \mathrm{~cm}$, Warren et al., 1999). According to Fig. 4 the modal ice thickness has decreased over the past 11 years, with a distinct reduction in ice thickness after 2004, when the mode dropped by $36 \%$ from $2.2 \mathrm{~m}$ (2004) to $1.4 \mathrm{~m} \mathrm{(2012).} \mathrm{Similar} \mathrm{observations} \mathrm{were} \mathrm{made} \mathrm{in} 2007$ at the North Pole by Haas et al. (2008). The interannual variability in modal thickness can be explained to some degree by different age compositions. For instance, the higher modal thickness in 2004 is likely the consequence of predominantly older ice (compare Figs. 2 and 3). However, there is no evidence of a change in age composition of surveyed ice towards younger ice that could explain the overall decline in 


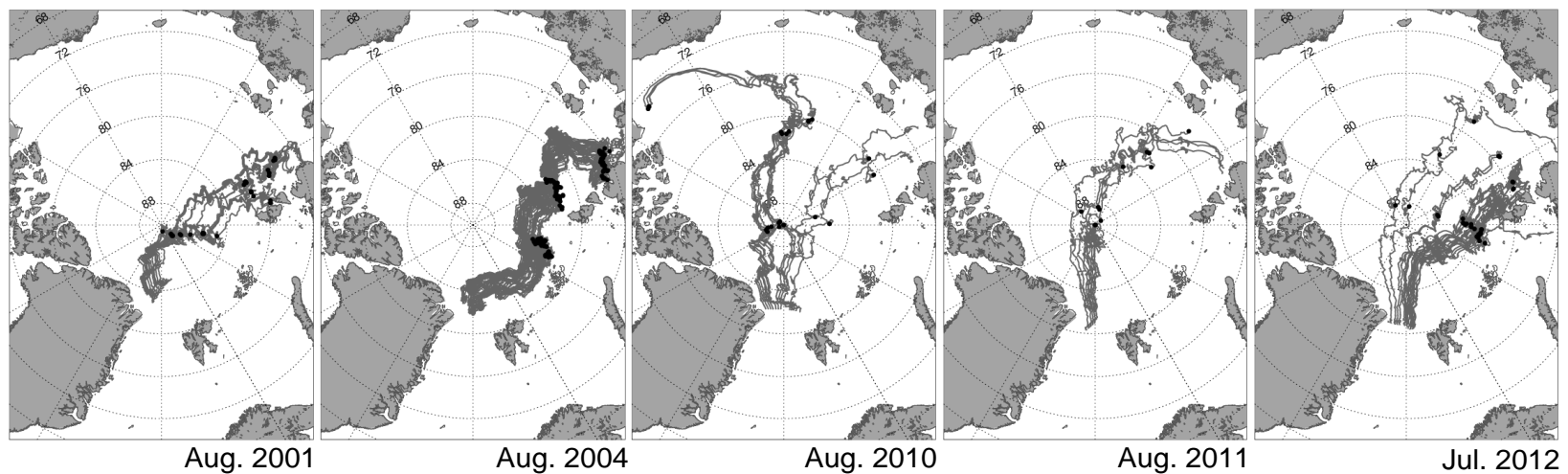

Figure 2. Backtracking of sampled sea ice using a combination of ice drift and concentration information. The start points of the trajectories (gray lines) are equivalent to the positions where EM measurements were obtained during the individual years. The black dots correspond to the position of particles on 21 September, when first-year ice becomes second-year ice, and second-year ice becomes multiyear ice.

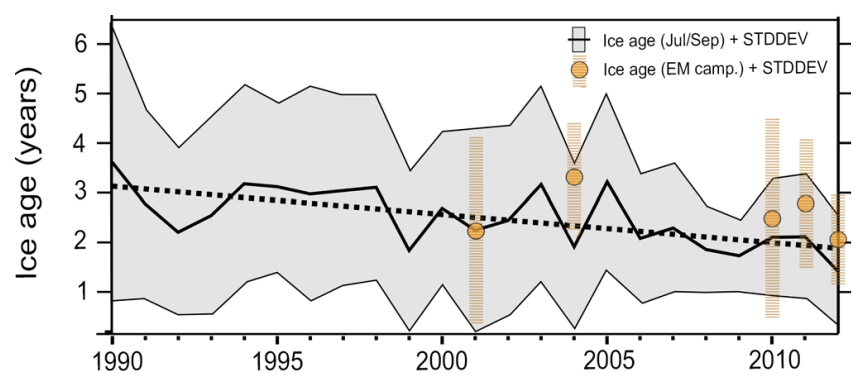

Figure 3. Comparison of age of sea ice covered by EM measurements and mean summer ice age in Fram Strait obtained from Maslanik et al. (2011): the black line represents the average JulySeptember ice age along the meridional and zonal gates through which satellite-derived ice area fluxes were calculated (compare red line in Fig. 1). A trend line is added (dashed black line). The age of sea ice covered by EM measurements between 2001 and 2012 is indicated by orange circles. The gray shaded area and dashed bars correspond to the standard deviation of ice age for satellite and observational data, respectively.

ice thickness. In fact, the length of pathways and age of surveyed ice in 2010 and 2012 does not differ much from 2001, but the modal thickness is significantly lower. Therefore, we assume that the decline in modal thickness observed in Fram Strait rather reflects the thinning of second-year and multiyear ice in the Laptev Sea (source area) and Transpolar Drift than decreasing age. The decrease in modal thickness is accompanied by a decrease in ridged ice (fraction of ice thicker than $3 \mathrm{~m}$ ). Note that in 2001 and 2004, the fraction of deformed ice is twice as high as in 2010, 2011 or 2012. Similar to the modal ice thickness, some of the interannual variability may be related to a varying age composition, but the overall decline is independent of ice age. Hence, the reduction of the deformed ice fraction points to a reduction in the deformation history in source areas and along pathways, mainly in the Laptev Sea and along the Transpolar Drift, which is in agree- ment with findings of Hansen et al. (2013, 2014). Following the authors, the decrease can be associated with changes in wind stress or a loss in perennial ice (decrease in ice age), since younger ice likely contains less consolidated pressure ridges. Another important factor that could explain the observed decrease in deformation is ocean heat, since melt rate is thickness dependent and an increase in ocean heat affects ridges much more than surrounding level ice. The decrease in ice extent (Meier et al., 2014), and the speed-up of ice drift along the pathways with the associated increase in lead fraction (Rampal et al., 2009) leads to an increased heat uptake which could in turn result in enhanced melt of deformed ice. The shrinking tail of the ice thickness distribution as well as the decrease in modal ice thickness is also reflected in the mean thickness. Figure 4 shows that during the past 11 years the mean thickness dropped by $16 \%$ from $2.58 \mathrm{~m}$ in 2001 to $2.17 \mathrm{~m}$ in 2012 . A slight increase in mean thickness takes place after 2010. The increase is related to an increase in the fraction of deformed ice between 2010 and 2012. This is in agreement with Hansen et al. (2014) who estimate that the contribution of thick, deformed ice towards the mean ice thickness is decreasing from about $70 \%$ in 2001 to about $50 \%$ in 2011.

The comparison of AEM- and GEM-based observations may introduce an additional uncertainty and must be limited to a comparable range of the thickness distribution. Although GEM data were obtained on a daily basis at representative locations along the ship track, the ground-based thickness surveys of 2001 are limited to large floes and predominantly level ice thick enough to walk on. In addition, the footprint of ground-based measurements is smaller than the footprint of airborne surveys which reduces footprint smoothing of pressure ridges. However, thickness distributions obtained by both methods in the same region have very similar shapes and modes (e.g., Haas et al., 2006, 2008, their Fig. 3), warranting their combination for this study. To further ensure compatibility with the AEM thicknesses, the GEM data have been 


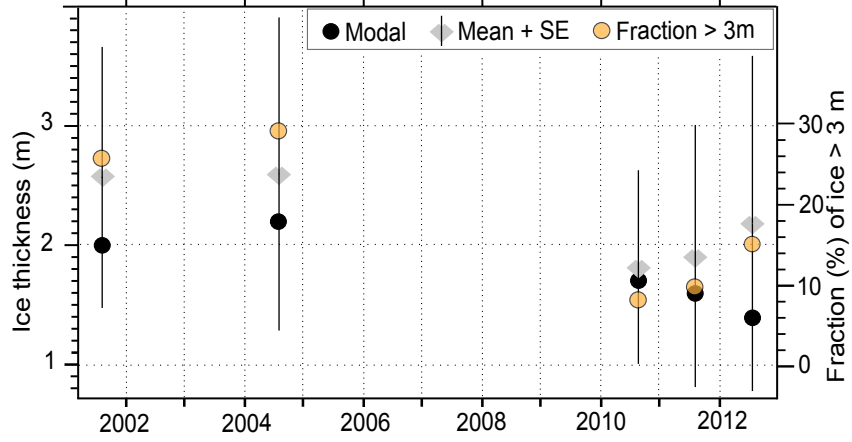

Figure 4. Mean (gray) plus standard deviation (black lines) and modal (black circles) EM ice thickness (ice plus snow $(0.1 \mathrm{~m})$ thickness) obtained in the Fram Strait region between 2001 and 2012 (left axis). The fraction of ice thicker than $3 \mathrm{~m}$ (right axis) is represented by orange circles. The locations of the performed survey flights is shown in Fig. 1.
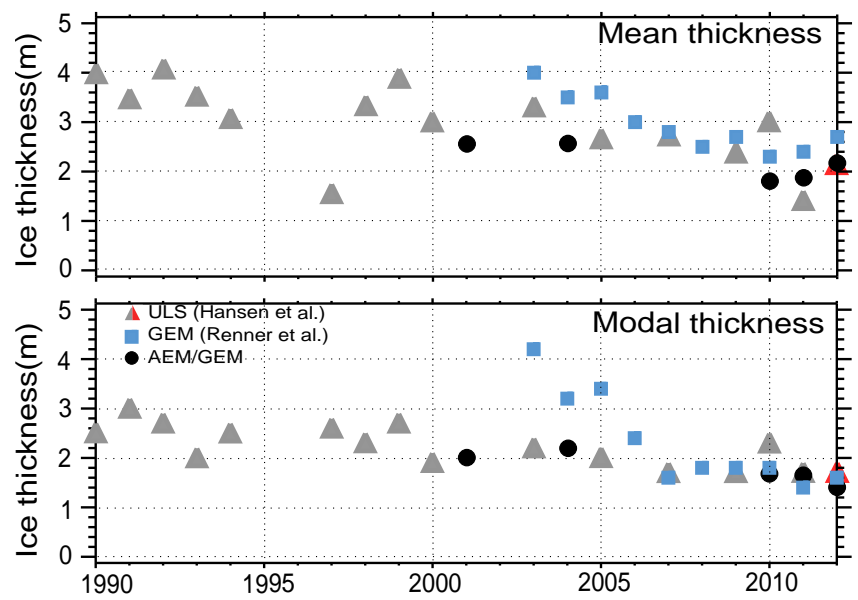

Figure 5. Comparison of mean (upper panel) and modal (lower panel) EM ice thicknesses (ice plus snow thickness) as obtained by ULS (source: Hansen et al., 2013), GEM (source: Renner et al., 2014) and GEM/AEM measurements in Fram Strait area. Gray/red triangles represent average August/July ULS measurements. The blue rectangles correspond to GEM measurements carried out between end of August and September. Black dots represent AEM/GEM measurements obtained during two cruises with RV Polarstern (August 2001 and 2004) and three surveys with the research aircraft Polar 5 (August 2010 and 2011, July 2012).

regridded to the sampling interval of the airborne data and ice thinner than $0.15 \mathrm{~m}$ and open water has been excluded from the analysis of the AEM measurements (see Sect. 2.1). For our study we assume that mean thicknesses obtained with both method are comparable as well. We base this assumption on the high number of available GEM surveys and the general exclusion of thin ice thicknesses from the AEM data, which will be vastly underrepresented in the GEM data.

\subsection{Comparison to other observations}

In Fig. 5 we compare our thickness measurements with thickness estimates made by Renner et al. (2014) and Hansen et al. (2013). By means of moored upward looking sonar (ULS) positioned between $79^{\circ} \mathrm{N}, 7^{\circ} \mathrm{W}$ and $79^{\circ} \mathrm{N}, 3^{\circ} \mathrm{W}$, Hansen et al. (2013) reconstructed a time series of sea ice thickness over 21 years (1990-2011). To enable a comparison with our observations, ULS thickness estimates in Fig. 5 are averaged August measurements, except for 2012 where averaged July measurements are used. Ice thickness measurements taken from Renner et al. (2014) were obtained with a GEM during cruises with RV Lance (Norwegian Polar Institute). Measurements cover the width of Fram Strait along approximately $79^{\circ} \mathrm{N}$ in September between 2003 and 2012. For details about data processing and handling we refer to Renner et al. (2014) and Hansen et al. (2013). A decrease in both, modal and mean thickness with a distinct reduction after 2004 is visible in all three data sets. According to the ULS observations, the mean and modal thickness in August is decreasing by $0.65 \mathrm{~m}$ and $0.41 \mathrm{mdecade}^{-1}$ between 1990 and 2012. GEM observations indicate an even more pronounced thinning of Fram Strait ice cover. A direct comparison of our observations with ULS- and GEM-based data is however difficult. In contrast to the AEM data, the ULS measurements consist of monthly averaged records obtained at single points located approximately $300 \mathrm{~km}$ further south. Nevertheless, despite the different locations the agreement between ULS and AEM data for August 2010 and 2011 and July 2012 is high. This indicates that a few but long AEM profiles provide representative information on ice thickness distribution even in areas of highly variable ice age and thickness composition such as Fram Strait. For the last 3 years, the agreement between AEM data and GEM measurements obtained by Renner et al. (2014) is high, too. Nevertheless, taking into account that GEM measurements by Renner et al. (2014) were obtained approximately 1 month later (September), one would expect the GEM thickness measurements to be lower than ULS and AEM data. According to Renner et al. (2014), the positive offset is likely related to the absence of thin ice classes in the observations and preferential sampling of the survey sites.

\subsection{Along- and across-strait thickness gradients}

The thinning due to atmospheric and oceanographic processes on southward-moving sea ice was investigated during two ice thickness surveys performed in the downstream direction. Figure 6a shows AEM profiles that were made on 4 August 2011 and 21 July 2012. The first profile started at $81^{\circ} \mathrm{N}, 0^{\circ} \mathrm{E}$ and covers a distance of $290 \mathrm{~km}$ (south to $79^{\circ} \mathrm{N}$, $10^{\circ} \mathrm{W}$ ).

According to aerial photos taken during the flight, the ice cover was rather homogeneous. Likewise, there is no gradient in ice concentration along the profile or changes 

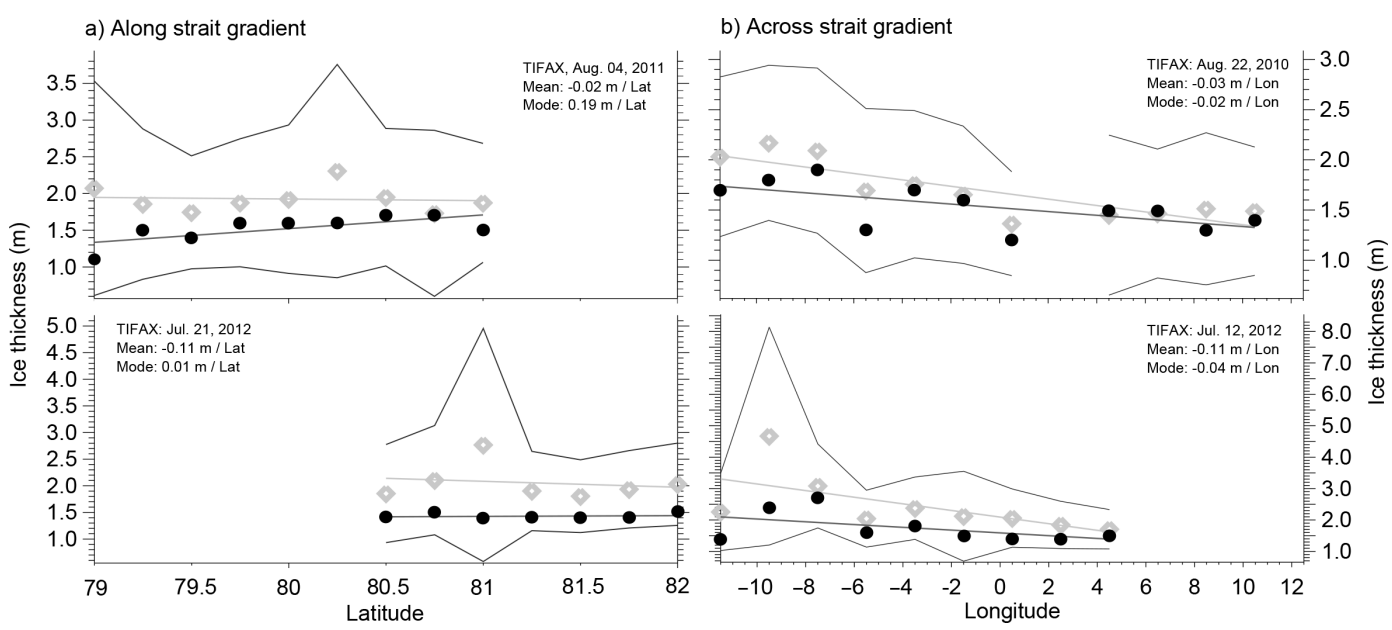

Figure 6. Across- and along- Fram Strait thickness gradients: (a) Along-strait flights made in August 2011 and 2012 between $10^{\circ} \mathrm{W}$ and $0^{\circ}$ E. (b): Across-strait flights made in 2010 (at $81^{\circ} \mathrm{N}$ ) and 2012 (at $82^{\circ} \mathrm{N}$ ). Gray rectangles correspond to the mean thickness with standard deviation (black solid lines), whereas black circles indicate modal thickness. The corresponding trend lines are plotted on top.

in the frequency of open-water occurrence. The high spatial variability in mean thickness makes an identification of a thickness gradient impossible. However, the modal thickness shows a continuous decrease of $0.19 \mathrm{mdegree}^{-1}$ latitude. The decrease in modal thickness is likely associated with oceanographic and atmospheric processes acting on the pack ice while drifting south: differences in net short- and longwave radiation and the presence of warm Atlantic water may lead to enhanced surface and bottom melt that could explain the observed gradient. A thinning of $0.38 \mathrm{~m}$ implies a heat flux of $16 \mathrm{Wm}^{-2}$. In principle, one could quantify the contribution of warm Atlantic water to sea ice melt via the determination of the atmospheric radiative fluxes and the transit time of sea ice between $81^{\circ} \mathrm{N}, 0^{\circ} \mathrm{E}$ and $79^{\circ} \mathrm{N}$, $10^{\circ} \mathrm{W}$. For example, using the backtracking approach as described in Sect. 2.2.3, we estimated the transit time of sea ice to be around 80 days. However, an exact determination of the transit time using low-resolution drift products is difficult, since their reliability is significantly reduced in the southern Fram Strait. In addition, atmospheric reanalysis products show large differences in radiative fluxes: the NCEP-based difference in net radiation between $81^{\circ} \mathrm{N}, 0^{\circ} \mathrm{E}$ and $79^{\circ} \mathrm{N}, 10^{\circ} \mathrm{W}$ amounts to $12 \mathrm{~W} \mathrm{~m}^{-2}$ for a transit time of 80 days. The difference in radiative fluxes based on ERAInterim data is much smaller $\left(2.5 \mathrm{~W} \mathrm{~m}^{-2}\right)$. Hence, an exact determination of oceanographic and atmospheric processes contributing to the observed gradient remains elusive without additional observations.

In 2012, a second $170 \mathrm{~km}$ long flight in the upstream direction was performed. Measurements were a continuation of the transect made in 2011 and started at $80.5^{\circ} \mathrm{N}$. The ice cover was again rather homogeneous with a few leads. According to Fig. 2 ice was formed in the western Laptev Sea and transported via the Transpolar Drift towards Fram
Strait. The absence of a gradient in modal thickness indicates that enhanced bottom or surface melt due to atmospheric or oceanographic processes is limited to areas south of $\approx 80^{\circ} \mathrm{N}$.

The ice thickness gradient across Fram Strait was investigated during two flights in 2010 (22 August) and 2012 (21 July). The long operating distance of Polar 5 enabled us to obtain the first continuous profiles over closed ice pack north of $81^{\circ} \mathrm{N}$. The across-strait ice thickness profile is presented in Fig. 6b. Both transects show a negative trend in modal $\left(0.02 \mathrm{~m}\right.$ and $0.04 \mathrm{~m}_{\text {degree }}{ }^{-1}$ longitude $)$ and mean $\left(0.03 \mathrm{~m}\right.$ and $0.11 \mathrm{mdegree}^{-1}$ longitude) ice thickness from West to East. The gradient in mean thickness is thereby more pronounced than the gradient in modal thickness. For sea ice at this latitude or higher, one can assume the impact of oceanographic and atmospheric processes on the ice cover to be smaller. This assumption is supported by the absence of a gradient in modal ice thickness for sea ice upstream of $80.5^{\circ} \mathrm{N}$ discussed above. Hence, we assume the observed gradient to be mainly associated with differences in age and deformation of ice provided by the Transpolar Drift system. A comparison to Fig. 2 reveals that the ice that enters Fram Strait west of the prime meridian is indeed older and therefore most likely thicker than ice that enters through the eastern section. Note that the good agreement between the length of pathways and observed thickness gives us confidence in the performance of the tracking approach.

Earlier quantifications of across-strait gradients were made by Hansen et al. (2013) and Renner et al. (2014) approximately $300 \mathrm{~km}$ further south at $79^{\circ} \mathrm{N}$. Their estimates are based on interpolations between single-point upwardlooking sonar measurements and on merged EM profiles obtained during different days. For this position, the authors reported a decline in across-strait modal thickness of 


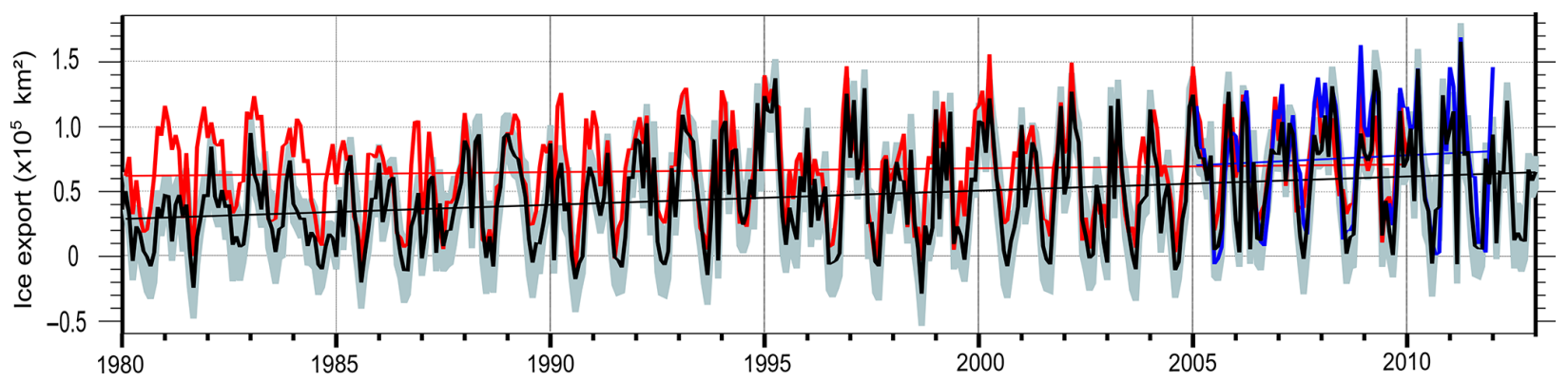

Figure 7. Monthly ice area export (given in $\times 10^{3} \mathrm{~km}^{2}$ ) across Fram Strait. The black line presents area fluxes calculated from NSIDC drift and concentration information across the meridional and zonal gates (compare Fig. 1). In gray, the corresponding uncertainty estimates are given. The blue and red lines indicate monthly sea ice area transports across $79^{\circ} \mathrm{N}, 15^{\circ} \mathrm{W}$ and $79^{\circ} \mathrm{N}, 5^{\circ} \mathrm{E}$ based on SAR images $(\mathrm{Kloster}$ and Sandven, 2011) and based on SLP gradients (Smedsrud et al., 2011), respectively. Trend lines for individual flux estimates are plotted on top.

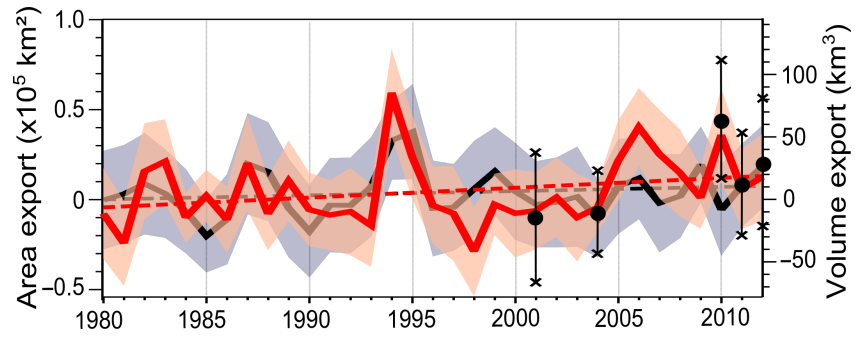

Figure 8. July (black) and August (red) ice area export across Fram Strait (given in $\times 10^{3} \mathrm{~km}^{2}$ ), plotted on top of the corresponding uncertainty estimates (gray and light red). Area fluxes were calculated from NSIDC drift and concentration data. The associated volume flux for the years where EM measurements are available is calculated as the product of NSIDC area flux estimates (August) and EM mean thickness (black dots, right axis). The error bars indicate uncertainties of volume estimates. Note that for 2012, where AEM measurements were made 1 month earlier, area transport rates for July were used.

-0.1 to -0.3 m degree $^{-1}$ longitude (Renner et al., 2014) and -0.23 m degree $^{-1}$ longitude (Hansen et al., 2013).

\subsection{Summer sea ice area and volume fluxes}

To quantify whether coupled sea ice ocean models are capable of reproducing Fram Strait sea ice volume fluxes correctly, validation data are required. Using satellite data, the volume flux in Fram Strait can be described as the product of southward-directed sea ice motion, concentration and mean thickness. Information on ice drift and concentration is available on a year-round basis. However, the availability of satellite-based thickness data from ICESat or CryoSat-2 are restricted to winter months, which is why ice volume flux estimates for summer periods are scarce. In the following, we will therefore use the presented EM measurements together with satellite-based area flux estimates to calculate volume outflows for the periods when thickness surveys were made.
Because of its year-round availability, ice area flux out of Fram Strait is calculated using NSIDC motion estimates together with NSIDC ice concentration information. Figure 7 shows the monthly ice area export across Fram Strait from 1980 to 2012 (black line) together with the associated uncertainty estimates (gray). Note that the area flux is the sum of meridional and zonal components, with a positive sign referring to ice export, and a negative sign indicating ice import into the Arctic (see Sect. 2.2.5). The average monthly ice area flux amounts to $46 \times 10^{3} \mathrm{~km}^{2}$ with a standard deviation of $38 \times 10^{3} \mathrm{~km}^{2}$ and an uncertainty of $\pm 18 \times 10^{3} \mathrm{~km}^{2}$. The monthly ice export shows a pronounced seasonal cycle with lowest fluxes in July and August and highest export rates between December and March. During summer, flux rates are significantly lower and can become even negative, such that ice is being imported from southern Fram Strait. The pronounced seasonal cycle and much of the interannual variability of ice area export are associated with changes in SLP gradients across the gate, because gradients are generally lower during summer months and higher during winter. In addition, sea ice concentration in Fram Strait is lower during summer months, which leads to reduced export rates between July and September. The reduced drift speed and ice concentration during summer (May-September) also results in higher uncertainties $\left( \pm 19 \times 10^{3} \mathrm{~km}^{2}\right)$. Likewise, during winter months, when average drift speed and ice concentration are higher, the uncertainty of area flux estimates is lower (October-April, $\pm 14 \times 10^{3} \mathrm{~km}^{2}$ ). Overall we find a positive trend in monthly Fram Strait area flux of $10.9 \times 10^{3} \mathrm{~km}^{2} \mathrm{decade}^{-1}$. The trend is significant at the $99 \%$ confidence level. Following Smedsrud et al. (2011) the increase in ice export is the consequence of a positive trend in the local pressure gradient, related to intensification of cyclones over the Nordic Seas. According to that study the sea ice area export has increased by about $25 \%$ since the 1960 s. The increase in ice export occurred mostly during winter and is directly connected to higher southward ice drift velocities, due to stronger geostrophic winds. In contrast, other studies 
(Kwok, 2009; Kwok et al., 2013) did not observe any significant trend in ice area export for the past decades.

The area export for July, August and September accounts for only $6.2 \%$ of the annual fluxes. The months with the lowest net contributions are July and August (1.4\%). Ice area export rates for both months are shown together with associated uncertainty estimates in Fig. 8 (black and red lines). The net sea ice export during July and August is positive, but estimates show considerable interannual variability with the highest rates occurring in August of 1994, 2006 and 2010 and lowest in 1981 and 1998. The average August ice area flux amounts to $4.3 \times 10^{3} \mathrm{~km}^{2}$ with a standard deviation (SE) of $19 \times 10^{3} \mathrm{~km}^{2}$ and an uncertainty of $\pm 21 \times 10^{3} \mathrm{~km}^{2}$. The average July ice flux is a bit lower $\left(3.8 \times 10^{3} \mathrm{~km}^{2} \pm 13 \times 10^{3} \mathrm{~km}^{2}\right)$ with higher uncertainties $\left( \pm 24 \times 10^{3} \mathrm{~km}^{2}\right)$. Note that there is a positive trend in the August and July ice export of $5.5 \times 10^{3}$ and $2.3 \times$ $10^{3} \mathrm{~km}^{2} \mathrm{decade}^{-1}$, respectively. The trend is however not statistically significant.

The associated volume fluxes for the years where GEM/AEM measurements are available (Fig. 8) is calculated as the product of area flux and mean GEM/AEM thickness minus the snow thickness assumptions we made for August. The uncertainty of volume fluxes is the product of area flux uncertainties and mean ice thickness plus the snow thickness uncertainty $( \pm 5.0 \mathrm{~cm})$. For 2012, where AEM measurements were made 1 month earlier, area transport rates for July (black line) were used. Given the low area export in July and August, the volume transport is low, too. For the investigated months, the average volume export amounts to $16.78 \mathrm{~km}^{3}$ with highest rates in August $2010\left(61.25 \mathrm{~km}^{3}\right)$ and lowest in August $2001\left(-15.35 \mathrm{~km}^{3}\right)$. The average uncertainty amounts to $\pm 44.48 \mathrm{~km}^{3}$.

The reliability of volume flux depends as well on the accuracy of sea ice motion information in summer as on the available ice and snow thickness information. An additional bias of $\pm 4 \%$ may arise from uncertainties in sea ice concentration during summer months. This error is however difficult to account for, since we expect it to vary with the presence of thin ice and melt ponds, atmospheric water vapor and watersurface roughening by wind (Ivanova et al., 2014). Assuming that the sea ice thickness PDFs are accurate, and uncertainties related to interannual variability in snow cover are small $( \pm 5 \mathrm{~cm})$, the biggest error in volume flux estimates arises from sea ice motion information. Due to the lack of sea ice motion observations obtained from drifting buoys in Fram Strait during summer months, we cannot evaluate the uncertainty of satellite-based sea ice motion information directly. Nevertheless, recent studies of Sumata et al. $(2014,2015)$ indicate that NSIDC ice motion information suffer from a general underestimation of drift during summer months and a generally reduced accuracy in the narrow Fram Strait. In particular, low drift velocities and ice concentration result in errors of up to $2.0 \mathrm{~cm} \mathrm{~s}^{-1}$. In this study we apply the uncertainty estimates provided by Sumata et al. (2015) for differ- ent drift speeds and ice concentration to evaluate reliability of our flux calculations. As an additional quality control we compare our results with area flux estimates from Kloster and Sandven (2011) and Smedsrud et al. (2011) (Fig. 7, red and gray line). Area flux calculations of Kloster and Sandven (2011) are based on ice concentration data and manually derived ice motion information from ENVISAT SAR images. SAR WideSwath image pairs were captured 3 days apart with uninterrupted year-round coverage from February 2004 to December 2011. Estimates were made across $79^{\circ} \mathrm{N}, 15^{\circ} \mathrm{W}$ and $79^{\circ} \mathrm{N}, 5^{\circ}$ E. Note that at $79^{\circ} \mathrm{N}$ Fram Strait is relatively narrow and therefore only a limited number of images are needed to cover the entire passage. According to the authors, the monthly mean export uncertainties amount to $5 \%$. Smedsrud et al. (2011) used the pressure difference (NCEP/NCAR reanalysis data) between $79^{\circ} \mathrm{N}, 25^{\circ} \mathrm{W}$ and $79^{\circ} \mathrm{N}, 5^{\circ} \mathrm{E}$ together with SAR-based flux estimates of Kloster and Sandven (2011) to estimate the linear regression between geostrophic winds, sea ice drift speed and ice area export. The linear relationship was then used to reconstruct ice area export based on pressure differences for the period between 1957 and 2010. A direct comparison of our area flux estimates with the findings of Smedsrud et al. (2011) and Kloster and Sandven (2011) is difficult, because area flux estimates are based on different methods and were made at different latitude gates. However, a comparison of our findings with area export estimates of others reveals that the trend in NSIDC export rates is much higher $\left(37.6 \% \mathrm{decade}^{-1}\right.$ for the period 1980-2012) than the trend found by Kloster and Sandven (2011) (22.2\% decade ${ }^{-1}$ for the period 2004-2011, compare Fig. 7) or the trend reported by Smedsrud et al. (2011) $\left(4.7 \%\right.$ decade $^{-1}$ for the period 1980-2010), and in contrast to Kwok (2009) and Kwok et al. (2013), who did not observe any significant trend in ice area export for the past decades. A discussion on causes of differences in observed trends is beyond the scope of this paper. Nevertheless, despite large differences in observed trends the concordance between our findings and estimates of Kloster and Sandven (2011) and Smedsrud et al. (2011) gives us confidence in our results. The agreement in seasonal variability indicates that there is a relative consistency between area fluxes: the correlation coefficient $(r)$ between NSIDC-based estimates and computations of Smedsrud et al. (2011) is 0.79 and between NSIDC area flux and SAR-based estimates 0.80. The agreement between SAR-, and SLP-based export rates are of the same order $(r=0.82)$. A comparison of absolute fluxes for the periods where NSIDC, NCEP/NCAR reanalysis data and SAR-based estimates are available (2004-2010) shows that our estimates are approximately 18 and $20 \%$ lower than estimates of Smedsrud et al. (2011) and Kloster and Sandven (2011). If the intercomparison is limited to summer months only (July-September), NSIDC-based export rates are within the range of SAR-based estimates $\left(27 \times 10^{3} \mathrm{~km}^{2}\right.$ vs. $28 \times 10^{3} \mathrm{~km}^{2}$ ), whereas computations based on pressure differences are higher $\left(53 \times 10^{3} \mathrm{~km}^{2}\right)$. 


\section{Conclusions}

We present a data set of ground-based and airborne electromagnetic (EM) ice thickness measurements covering Fram Strait and the southern part of the Transpolar Drift in summer between 2001 and 2012. The data set adds to existing ice thickness information, with the addition of long transects that can only be obtained by fixed-wing aircrafts.

An investigation of pathways and source areas of surveyed sea ice shows that the largest fraction of ice has been formed in the Laptev Sea. The average age of ice covered by EM measurements is between 2.1 and 3.3 years. Keeping limitations of the rather short and irregular-spaced time series in mind, the EM data provide evidence of a changing Fram Strait sea ice cover. As seen also in other, independent data sets, the observed decrease in modal thickness between 2001 and 2012 likely reflects a thinning of second-year and multiyear ice cover leaving the Arctic Basin through Fram Strait. The decrease in modal thickness is accompanied by a decrease in mean thickness and fraction of ice thicker than $3 \mathrm{~m}$.

The thinning effect of atmospheric and oceanographic processes on southward-moving sea ice was investigated during two ice thickness surveys performed in the downstream direction. A decrease in modal thickness of $0.19 \mathrm{~m} \mathrm{degree}^{-1}$ latitude south of $81^{\circ} \mathrm{N}$ is likely associated with atmospheric and oceanic processes, leading to enhanced surface and bottom melt. Further north, the variability in ice thickness is more likely related to differences in age and deformation of ice.

Together with satellite-based area flux estimates, we used our thickness measurements to calculate volume fluxes during summer months and associated uncertainties. Ice area flux estimates are performed using satellite-based ice concentration and drift data. In agreement with Smedsrud et al. (2011) we find a significant positive trend in monthly Fram Strait area flux. The summer (July and August) ice area export is low compared to the annual values with high uncertainties. For the investigated months, the average volume export amounts to $16.78 \mathrm{~km}^{3}$ with highest rates in August 2010 $\left(61.25 \mathrm{~km}^{3}\right)$ and lowest in August $2001\left(-15.35 \mathrm{~km}^{3}\right)$. Naturally, the volume flux estimates are limited to the period when airborne thickness surveys are available. Nevertheless, we could show that the combination of satellite data and airborne observations can be used to determine volume fluxes through Fram Strait and as such, be used to bridge the lack of satellite-based sea ice thickness information in summer. Therefore, airborne thickness surveys in Fram Strait should be continued and extended in the future.
Acknowledgements. We thank the crew of the research aircraft Polar 5, the helicopter crew of RV Polarstern, the crew of Station Nord in Greenland, and Manuel Sellmann and Martin Gehrmann (AWI) for their great logistical support and helping hands during campaigns. We acknowledge Kjell Kloster (Nansen Environmental and Remote Sensing Center, Norway) for providing his Fram Strait outflow estimates and Angelika Renner (Institute of Marine Research, Norway) and Edmond Hansen (Norwegian Polar Institute, Norway) for supplying us with GEM and ULS measurements. AMSR-E and SSM/I brightness temperatures and ice drift data were provided by the NSIDC (Boulder, USA). This work was carried out as part of the Russian-German cooperation System Laptev Sea, funded by the BMBF under grant 03G0639A and the Alfred Wegener Institute and the Research Council of Norway (CORESAT project, 222681). The work of S. Hendricks was funded by the German Ministry of Economics and Technology (Grant 50EE1008).

Edited by: J. Stroeve

\section{References}

Beszczynska-Moeller, A., Fahrbach, E., Schauer, U., and Hansen, E.: Variability in Atlantic water temperature and transport at the entrance to the Arctic Ocean, 1997-2010, J. Mar. Sci., 69, 852-863, doi:10.1093/icesjms/fss056, 2012.

Comiso, J. C.: Bootstrap Sea Ice Concentrations from Nimbus7 SMMR and DMSP SSM/I-SSMIS, Tech. Rep., NASA National Snow and Ice Data Center, Boulder, CO, USA, doi:10.5067/J6JQLS9EJ5HU, 2000.

Comiso, J. C. and Hall, D. K.: Climate trends in the Arctic as observed from space, Interdiscipl. Rev.-Clim. Change, 5, 389-409, doi:10.1002/Wcc.277, 2014.

Fowler, C., Emery, W., and Tschudi, M.: Polar Pathfinder Daily $25 \mathrm{~km}$ EASE-Grid Sea Ice Motion Vectors, Version 2, Daily and Mean Gridded Field, Tech. Rep., NASA DAAC at the National Snow and Ice Data Center, Boulder, CO, USA, 2013.

Girard-Ardhuin, F. and Ezraty, R.: Enhanced Arctic sea ice drift estimation merging radiometer and scatterometer data, IEEE Trans. Geosci. Remote Sens., 50, 7, 2629-2648, doi:10.1109/TGRS.2012.2184124, 2012.

Haas, C.: Late summer sea ice thicness variability in the Arctic Transpolar Drift 1991-2001 derived from ground-based electromagentic soundings, Geophys. Res. Lett., 31, L09402, doi:10.1029/2003GL019394, 2004

Haas, C., Hendricks, S., and Doble, M.: Comparison of the sea ice thickness distribution in the Lincoln Sea and adjacent Arctic Ocean in 2004 and 2005, Ann. Glaciol., 44, 247-252, doi:10.3189/172756406781811781, 2006.

Haas, C., Pfaffling, A., Hendricks, S., Rabenstein, L., Etienne, J. L., and Rigor, I.: Reduced ice thickness in Arctic Transpolar Drift favors rapid ice retreat, Geophys. Res. Lett., 35, L17501, doi:10.1029/2008GL034457, 2008

Haas, C., Lobach, J., Hendricks, S., Rabenstein, L., and Pfaffling, A.: Helicopter-borne measurements of sea ice thickness, using a small and lightweight, digital EM system, J. Appl. Geophys., 67, 234-241, 2009. 
Haas, C., Hendricks, S., Eicken, H., and Herber, A.: Synoptic airborne thickness surveys reveal state of Arctic sea ice cover, Geophys. Res. Lett., 37, L09501, doi:10.1029/2010GL042652, 2010.

Hansen, E., Gerland, S., Granskog, M. A., Pavlova, O., Renner, A. H., Haapala, J., Loyning, T. B., and Tschudi, M.: Thinning of Arctic sea ice observed in Fram Strait: 1990-2011, J. Geophys. Res., 118, 5202-5221, doi:10.1002/jgrc.20393, 2013.

Hansen, E., Ekeberg, O.-C., Gerland, S., Pavlova, O., Spreen, G., and Tschudi, M.: Variability in categories of Arctic sea ice in Fram Strait, J. Geophys. Res., 119, 7175-7189, doi:10.1002/2014JC010048, 2014.

Kloster, K. and Sandven, S.: Ice Motion and Ice Area Flux in Fram Strait at $79^{\circ} \mathrm{N}$ Using ASAR and Passive Microwave for February 2004-July 2010, Tech. report 322, Nansen Environmental and Remote Sensing Centre, Bergen, Norway, 2011.

Holland, M., Serreze, M., and Stroeve, J.: The sea ice mass budget of the Arctic and its future change as simulated by coupled climate models, Clim. Dynam., 34, 2, 185-200, doi:10.1007/s00382-008-0493-4, 2010.

Ivanova, N., Johannessen, O. M., Pedersen, L. T., and Tonboe, R. T.: Retrieval of Arctic Sea Ice Parameters by Satellite Passive Microwave Sensors: A Comparison of Eleven Sea Ice Concentration Algorithms, Geosci. Remote Sens., 7233-7246, doi:10.1109/TGRS.2014.2310136, 2014.

Krumpen, T., Janout, M., Hodges, K. I., Gerdes, R., GirardArdhuin, F., Hölemann, J. A., and Willmes, S.: Variability and trends in Laptev Sea ice outflow between 1992-2011, The Cryosphere, 7, 349-363, doi:10.5194/tc-7-349-2013, 2013.

Kwok, R.: Outflow of Arctic Ocean Sea Ice into the Greenland and Barents Seas: 1979-2007, J. Climate, 22, 2438-2457, doi:10.1175/2008JCLI2819.1, 2009.

Kwok, R., Spreen, G., and Pang, S.: Arctic sea ice circulation and drift speed: decadal trends and ocean currents, J. Geophys. Res., 118, 2408-2425, 2013.

Lindsay, R. and Schweiger, A.: Arctic sea ice thickness loss determined using subsurface, aircraft, and satellite observations, The Cryosphere, 9, 269-283, doi:10.5194/tc-9-269-2015, 2015.

Mahoney, A., Eicken, H., Fukamachi, Y., Ohshima, H., Shimizu, D., Kambhamettu, C., Hendricks, S., and Jones, J.: Taking a look at both sides of the ice: comparison of ice thickness and drift speed as observed from moored, airborne and shore-based instruments near Barrow, Alaska, Ann. Glaciol., 69, 69A565, 363-372, doi:10.3189/2015AoG69A565, 2014.

Martin, T., Steele, M., and Zhang, J.: Seasonality and long-term trend of Arctic Ocean surface stress in a model, J. Geophys. Res., 119, 1723-1738, doi:10.1002/2013JC009425, 2014.

Maslanik, J. A., Stroeve, J., Fowler, C., and Emery, W.: Distribution and trends in Arctic sea ice age through spring 2011, Geophys. Res. Lett., 38, L13502, doi:10.1029/2011GL047735, 2011.

Maykut, G. A. and Untersteiner, N.: Some results from a timedependent thermodynamic model of sea ice, J. Geophys. Res., 76, 6, 1550-1575, doi:10.1029/JC076i006p01550, 1971.

Meier, W. N., Hovelsrud, G. K., van Oort, B. E., Key, J. R., Kovacs, K. M., Michel, C., Haas, C., Granskog, M. A., Gerland, S., Perovich, D. K., Makshtas, A., and Reist, J. D.: Arctic sea ice in transformation: a review of recent observed changes and impacts on biology and human activity, Rev. Geophys., 52, 185217, doi:10.1002/2013RG000431, 2014.
Miller, P. A., Laxon, S. W., Feltham, D. L., and Gresswell, J.: Optimization of a sea ice model using Basinwide observations of arctic sea ice thickness, extent, and velocity, J. Climate, 19, 10891108, doi:10.1175/JCLI3648.1, 2006.

Pfaffling, A., Haas, C., and Reid, J. E.: A direct helicopter EM sea ice thickness inversion, assessed with synthetic and field data, Geophysics, 72, F127-F137, 2007.

Rabenstein, L., Hendricks, S., Martin, T., Pfaffhuber, A., and Haas, C.: Thickness and surface properties of different sea ice regimes within the Arctic Trans Polar Drift: data from summers 2001, 2004 and 2007, J. Geophys. Res., 115, C12059, doi:10.1029/2009JC005846, 2010.

Rampal, P., Weiss, J., and Marsan, D.: Positive trend in the mean speed and deformation rate of Arctic sea ice, 1979-2007, J. Geophys. Res., 114, C05013, doi:10.1029/2008JC005066, 2009.

Renner, A. H., Gerland, S., Haas, C., Spreen, G., Beckers, J. F., Hansen, E., Nicolaus, M., and Goodwin, H.: Evidence of Arctic sea ice thinning from direct observation, Geophys. Res. Lett., 41, 5029-5036, doi:10.1002/2014GL060369, 2014.

Rigor, I. G. and Colony, R. L.: Sea-ice production and transport of pollutants in the Laptev Sea, 1979-1992, Sci. Total Environ., 202, 89-110, doi:10.1016/S0048-9697(97)00107-1, 1997.

Rozman, P., Hoelemann, J., Krumpen, T., Gerdes, R., Koeberle, C., Lavergne, T., and Adams, S.: Validating satellite derived and modelled sea-ice drift in the Laptev Sea with in situ measurements from the winter of 2007/08, Polar Res., 30, 67218, doi:10.3402/polar.v30i0.7218, 2011.

Smedsrud, L. H., Sirevaag, A., Kloster, K., Sorteberg, A., and Sandven, S.: Recent wind driven high sea ice area export in the Fram Strait contributes to Arctic sea ice decline, The Cryosphere, 5, 821-829, doi:10.5194/tc-5-821-2011, 2011.

Spreen, G., Kern, S., Stammer, D., and Hansen, E.: Fram Strait sea ice volume export estimated between 2003 and 2008 from satellite data, Geophys. Res. Lett., 36, L19502, doi:10.1029/2009GL039591, 2009.

Spreen, G., Kwok, R., and Menemenlis, D.: Trends in Arctic sea ice drift and tole of wind forcing: 1992-2009, Geophys. Res. Lett., 38, 1-14, doi:10.1029/2011GL048970, 2011.

Sumata, H., Lavergne, T., Girard-Ardhuin, F., Kimura, N., Tschudi, M., F., K., Karcher, M., and Gerdes, R.: An intercomparison of Arctic ice drift products to deduce uncertainty estimates, J. Geophys. Res., 119, 4887-4921, doi:10.1002/2013JC009724, 2014.

Sumata, H., Kwok, R., Gerdes, R., Kauker, F., Karcher, M.: Uncertainty of Arctic summer ice drift assessed by highresolution SAR data, J. Geophys. Res., 120, 5285-5301, doi:10.1002/2015JC010810, 2015.

Stroeve, J. and Notz, D.: Insights on past and future sea-ice evolution from combining observations and models., Global Planet. Change, 135, 119-132, doi:10.1016/j.gloplacha.2015.10.011, 2015.

Warren, S. G., Rigor, I. G., Untersteiner, N., F., R. V., Bryzgin, N. N., Aleksandrov, Y. I., and Colony, R.: Snow depth on Arctic sea ice, J. Climate, 12, 1814-1829, 1999. 